\title{
BIRDS NEAR FORT GOOD HOPE, NORTHWEST TERRITORIES.
}

\author{
by HARALD B. BROCH*
}

(EDITOR'S NOTE: The author compiled the following list of 47 species during a 15 month period at Fort Good Hope, May 1972, to August 1973. His thesis studies were mainly directed towards cultural and human ecology. He does not pretend that the list is comprehensive and has not reviewed the literature. Fort Good Hope is on the Mackenzie River about 250 miles south of the Arctic Coast.)

\section{EXPLANATION OF SYMBOLS}

$$
\begin{aligned}
\stackrel{?}{-} & =\text { uncertain characteristics } \\
\mathrm{O} & =\text { more than } 5 \text { observations } \\
\mathrm{x} & =\text { more than } 50 \text { observations } \\
- & =\text { less than } 5 \text { observations } \\
\mathrm{t} & =\text { observed migrating } \\
\mathrm{y} & =\text { young } \\
+ & =\text { also commonly seen at other } \\
& \text { places than those specified } \\
\mathrm{H}= & \text { by date }
\end{aligned}
$$

F.G.H. = Fort Good Hope

ARCTIC LOON. This species was commonly seen both on the Mackenzie River and on small lakes in this area.

\section{1/6/72 Fossil Lake \\ 30/6/72 Mackenzic River by Loon River}

HORNED GREBE.

$\begin{array}{rrl}+\quad 6 / 8 / 72 & \begin{array}{l}\text { South of San Sault } \\ \text { Mackenzie River }\end{array} \\ -H \quad 31 / 5 / 72 & \begin{array}{l}\text { On small lake by } \\ \text { Ontaritue River }\end{array}\end{array}$

WHISTLING SWAN. Was observed most frequently during spring migration, 1973. The migration seemed to reach its peak in the second week of May. For about 5 days the birds were flying steadily north in the

* Department of Sucial Anthropology,

University of Bergen,

N-5000 Bergen, Norway. morning and most of the day, while great numbers returned on a southbound flight early at night. The same migration pattern could be observed for Canada Goose, White-fronted Goose and Snow Goose.

$$
\begin{aligned}
& +\quad \text { o } 30 / 6 / 72 \text { Mackenzic River just } \\
& \text { xt May/73 Mackenzie River } \\
& \text { by the mouth of } \\
& \text { Ontaritue River }
\end{aligned}
$$

CANADA GOOSE. This species was often noticed migrating with Whitefronted Geese. At the mouth of Ontaritue River we noticed Canada

\begin{tabular}{|c|c|c|}
\hline$x$ & $5 / 8 / 72$ & $\begin{array}{l}\text { Islands north of } \\
\text { San Sault Ranids }\end{array}$ \\
\hline$x t$ & May/73 & $\begin{array}{l}\text { Maekenzie River by the } \\
\text { mouth of Ontaritue }\end{array}$ \\
\hline$-\mathrm{H}$ & June $/ 73$ & $\begin{array}{l}\text { River } \\
\text { Mackenzie River, just }\end{array}$ \\
\hline$o H$ & $8 / 6 / 73$ & $\begin{array}{l}\text { north of Ontaritue Rive } \\
\text { Upper Ramparts River }\end{array}$ \\
\hline
\end{tabular}
Geese flying in pairs as early as the middle of May; sometimes they were observed towards the end of this month grazing side by side on green pastures. On August 5, 1972, about 60 Canada Geese were observed molting, 10-15 miles north of San Sault Rapids. In the upper area of Ramparts River about 30 geese were observed feeding on the low green riverbanks. My companions informed me that geese were often seen here and they remembered noticing them at this place also when the birds were molting.

WHITE-FRONTED GOOSE.

xt June/73 Maekenzie River by the mouth of Ontaritue River

SNOW GOOSE.

xt June/73 Mackenzie River by the mouth of Ontarituo River

()t $18 / 9 / 72$ F.G.H. 
MALLARD. This duck is to be seen almost everywhere.

$\begin{array}{rrl}+\quad & 16 / 6 / 72 & \text { F.G.H. } \\ -H & 23 / 6 / 72 & \text { Hare Indian River } \\ 0 & 9 / 9 / 72 & \text { Hare Indian River } \\ & & \text { and Loche Lake } \\ - & 6 / 5 / 73 & \text { Ontaritue River } \\ \text { x } & 7 / 5 / 73 & \text { Ontaritue River }\end{array}$

PINTAIL. During May, 1973, this duck was among the first to arrive at Ontarituc River and totally dominated the first days. The first duck was scen on May 6: a Mallard. The next night the air was filled with ducks, mainly Pintails. At night the ducks were constantly in the air, as the watcrholes still frozc carly in the morning.

$\begin{array}{rrl}+\quad 30 / 6 / 72 & \text { Maekenzie River by } \\ & \text { F.G.H. } \\ \text { () } \quad 9 / 9 / 72 & \begin{array}{l}\text { Hare Indian River } \\ \text { and Loehe Lake }\end{array} \\ & 6 / 5 / 73 & \text { Ontaritue River }\end{array}$

\section{GREEN-WINGED TEAL.}

$\begin{array}{rrl}+\quad 18 / 5 / 72 & \text { Hare Indian River } \\ & 11 / 6 / 72 & \text { Fossil Lake } \\ \text { () } & 30 / 8 / 72 & \text { Hare Indian River } \\ - & 8 / 9 / 72 & \text { Loche Lake } \\ \text { () } & 28 / 5 / 73 & \text { Small lakes elose to } \\ & & \text { Ontaritue River }\end{array}$

AMERICAN WIGEON. As the duck spring migration wore off in the Ontaritue River area in the spring of 1973, wigeons remained and were soon the most common duck to be seen. Late in July I visited some small lakes close to this river and on several of them 20-40 young ducks of this ppecies were swimming. When disurbed they ran ashore.

$\begin{array}{rrl}+\quad & 5 / 8 / 72 & \text { Mackenzic River south } \\ \text { of F.G.H. } \\ \text { xH } & 30 / 5 / 73 & \text { On Ontaritue River } \\ \text { xy } & 27 / 7 / 73 & \text { Ontaritue River }\end{array}$

NORTHERN SHOVELER. This species seemed to arrive somewhat later than most other ducks in the spring of 1973 in the Ontaritue River area. The only place they were observed in any significant number was on a mud/sand bar on the Mackenzie a few niles north of the mouth of Ontaritue River. On small remote lakes in the upper parts of this river shovelers probably breed.

(1) 26/5/73 Mackenzie River and Ontaritue River (1) small lakes nearby

\section{RING-NECKED DUCK.}

10/6/72 Fossil Lake

\section{CANVASBACK.}

26/5/73 Ontarituc River

\section{GREATER SCAUP.}

() 9/9/72 Hare Indian River and Loche Lake

\section{LESSER SCAUP.}

\begin{tabular}{|c|c|c|}
\hline 0 & $11 / 6 / 72$ & Fossil River and I_ake \\
\hline () & $16 / 6 / 72$ & I_oehe I_ake \\
\hline () & $9 / 9 / 72$ & $\begin{array}{l}\text { Hare Indian River and } \\
\text { Loche Lake }\end{array}$ \\
\hline & $28 / 5 / 7$ & $\begin{array}{c}\text { Small lakes close to } \\
\text { Ontaritue River }\end{array}$ \\
\hline
\end{tabular}

COMMON GOLDENEYE. In late May, 1973, some 10 pairs of this species were observed on some small lakes a little north of Ontaritue River. These lakes were surrounded by dense old woods.

$$
\begin{aligned}
8 / 6 / 72 & \text { Hare Indian River } \\
\text { () June/73 } & \text { Small lakes close to } \\
& \text { Ontaritue River }
\end{aligned}
$$

BUFFLEHEAD.

() 1/6/73 Small lake close to Ontaritue River

OLDSQUAW. At Loche Lake two pairs of this species were observed on June 16, 1972. Late May flocks were flying continually low over the Mackenzie, northbound.

$$
\begin{array}{cl}
\text { xt } 30 / 5 / 73 & \text { Mackenzie River by the } \\
\text { mouth of Ontaritue } \\
\text { River }
\end{array}
$$

WHITE-WINGED SCOTER. Males of this species were observed migrating southwards on June 28, 1973. Native theory has it that all "black duck" males go south before the young and the femalcs. 


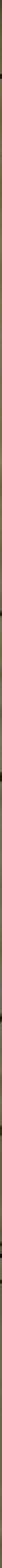

Map of the Fort Good Hope area.

$\begin{array}{lll}\text { o) } & 16 / 6 / 72 & \text { Loehe Lake } \\ \text { ot } 26 / 9 / 72 & \text { Maekenzie River close } \\ \text { to F.G.H } & \\ \text { ot } 5 / 10 / 72 & \begin{array}{l}\text { Maekenzie River close } \\ \text { to F.G.H. }\end{array} \\ \text { ot } 28 / 7 / 73 & \begin{array}{l}\text { Maekenzie River close } \\ \text { to Little Chieago }\end{array}\end{array}$

SURF SCOTER. This species is by far the most common scoter in the Fort Good Hope area. Both the Surf Scoter, the White-winged Scoter and the Black (Common) Scoter are called "black ducks" by the natives of this area. These are the most popular ducks because of their orange fat and large size. Surf Scoters seem to be breeding at Loche Lake.

\begin{tabular}{|c|c|c|}
\hline () & $11 / 6 / 72$ & Fossil Lake \\
\hline$x$ & $16 / 6 / 72$ & $\begin{array}{l}\text { Hare Indian River } \\
\text { and Loche Lake }\end{array}$ \\
\hline$x y$ & $9 / 9 / 72$ & $\begin{array}{l}\text { Hare Indian River } \\
\text { and Loche Lake }\end{array}$ \\
\hline$x t$ & $29 / 9 / 72$ & $\begin{array}{l}\text { Matekenzie River, } \\
\text { F.G.H. }\end{array}$ \\
\hline () & $21 / 5 / 73$ & $\begin{array}{l}\text { Small lakes close to } \\
\text { Ontaritue River }\end{array}$ \\
\hline
\end{tabular}

\section{BLACK (COMMON) SCOTER.}

\author{
() $16 / 6 / 72$ Loehe Lake \\ ()t 26/9/72 Maekenzie River F.G.H.
}

RED-BREASTED MERGANSER.

$\begin{array}{rrr}+\quad & 23 / 6 / 73 & \text { Hare Indian River } \\ -y & 19 / 8 / 73 & \text { Hare Indian River }\end{array}$

GOLDEN EAGLE. A big eagle was observed high in the sky on May 29. 1973. My companions said it was a Golden Eagle and I came to the same conclusion as I could find no sign of white on the bird.

SPRUCE GROUSE. Common around Fort Good Hope: most frequently observed late fall and early winter. I did not see any birds of this species in the late winter of 1973.

$$
\text { + () 26/9/72 F.G.H. }
$$


$9 / 12 / 73 \quad 30$ miles north of F.G.H.

SHARP-TAILED GROUSE. Commonly seen in late winter at Fort Good Hope. Sharp-tailed Grouse were not observed in late fall, 1972. The natives claim that this species is more shy than the Spruce Grouse. They are both called chickens; this term does not include ptarmigans.

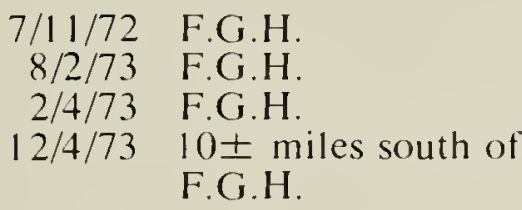

WILLOW PTARMIGAN. This species was commonly seen at Fort Good Hope after snowfall. I observed that some ptarmigans I shot before Christmas, 1972, were pink. This was particularly conspicuous when the birds were lying in the snow. The game warden in the settlement told me that he had seen pink ptarmigans the previous year. The pink colour, however, disappeared as winter wore on. Ptarmigans observed in January, 1973 , and the rest of the winter were all pure white.

$\begin{array}{lrl}\text { o } & 10 / 10 / 72 & \text { F.G.H. } \\ 0 & 21 / 11 / 72 & \text { F.G.H. } \\ 0 & 6 / 12 / 72 & \text { South of F.G.H. } \\ \text { x } & 8 / 2 / 73 & \text { F.G.H. } \\ 0 & 20 / 2 / 73 & \text { F.G.H. } \\ 0 & 2 / 4 / 73 & \text { F.G.H. }\end{array}$

ROCK PTARMIGAN. This species was only observed once, but is probably more common than my observations indicate. The Indians of Fort Good Hope classify both Rock and Willow Ptarmigan as "ptarmigan", making no distinction between the two.

$$
\text { () } 2 / 4 / 73 \text { F.G.H }
$$

SANDHILL CRANE. The Sandhill Crane seems to be abundant in the upper Ontaritue area. When walking in the bush from May 21 through 24, 1973, I frequently saw and heard these birds

$\begin{array}{rrl}\text { ot } & 24 / 5 / 72 & \text { F.G.H } \\ \text { o } & 5 / 8 / 72 & \text { Mackenzic River south } \\ & & \text { of F.G.H. } \\ \text { oH } & 24 / 5 / 73 & \text { Upper Ontaritue River }\end{array}$

COMMON SNIPE.

June/72 F.G.H

\section{SPOTTED SANDPIPIER.}

$+{ }^{\circ H}$ May/73 Ontaritue River area

LESSER YELLOWLEGS.

+ (1) May/73 Ontaritue River area

ARCTIC TERN.

17/6/72 Loche Lake

HAWK OWL. The first time I came across this bird I was out hunting ptarmigan and had just shot one. Suddenly an owl swept down from nowhere and grabbed my dead ptarmigan. Hawk Owls were often observed sitting in black-spruce tops.

$$
+\quad-19 / 3 / 73 \text { F.G.H. }
$$

GREAT GRAY OWL.

\section{- Nov./72 F.G.H}

BELTED KINGFISHER. This bird probably breeds at Jackfish Creek by F.G.H., Ontaritue River, and Loche Lake River, as they could be observed all summer 1972-73.

$\begin{array}{ll}19 / 6 / 72 & \text { Hare Indian River } \\ 19 / 6 / 72 & \text { Loche Lake River } \\ 20 / 5 / 72 & \text { F.G.H., Jackfish Creek } \\ \text { June/72 } & \text { Ontaritue River } \\ 18 / 5 / 73 & \text { Ontaritue River }\end{array}$

YELLOW-SHAFTER FLICKER. This bird was observed only once Snafu Creek about 20 miles south of Fort Good Hope on November 3, 1972 , in a forest destroyed by fire.

\section{NOR THERN THREE-TOED WOODPECKER}

6/12/72 F.G.H.

GRAY JAY. This species is abundant in the Fort Good Hope area. In late fall and winter it is often a nuisance to marten trappers because it eats the bait 
from the traps and quite often gets trapped.

22/11/72 Common around F.G.H.

\section{COMMON RAVEN.}

$+\quad$ 1/1/73 Resident at F.G.H.

BOREAL CHICKADEE.

12/10/72 F.G.H.

AMERICAN ROBIN.

$+{ }^{\circ} \mathrm{H} \quad 6 / 7 / 72$ F.G.H.

YELLOW WARBLER

3/7/72 F.G.H

PINE GROSBEAK.

() $12 / 4 / 73$ F.G.H.

COMMON REDPOLL

$+\quad-19 / 10 / 72$ F.G.H.

WHITE-WINGED CROSSBILL

() $6 / 2 / 73$ F.G.H

WHITE-CROWNED SPARROW.

$+\circ H \quad 5 / 5 / 72 \quad$ F.G.H

SNOW BUNTING. This species was only observed once, on September 28 , 1972, when a large flock stayed in the settlement of Fort Good Hope for 3 or 4 days.

\section{HARLEQUIN DUCK AT SASKATOON}

by WAYNE HARRIS*

On June 22, 1973, at about 12:30 p.m., E. A. Driver and I were watching Common Suckers trying to jump the

${ }^{*}$ Bor 93 ,

Raymore, Saskatchewan.

SOA 3J0 weir'on the South Saskatchewan River adjacent to the university campus in Saskatoon when a male Harlequin Duck swam out from the bank just above the dam. As neither of us had binoculars, I returned to the office for a pair plus a camera.

Upon my return the duck was feeding about 30 yards from shore. While I tried to get close enough to take some photographs Ed and two others who had returned with me, Vic Lieffers and Don Peden, watched the bird. I approached within 30 yards and took several photographs of the duck between his dives.

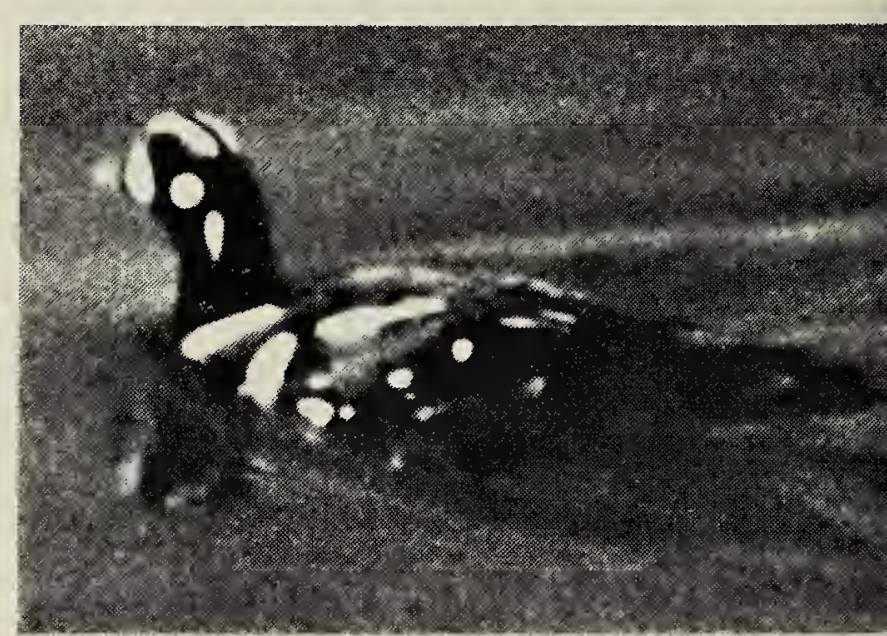

Harlequin Duck

Wayne Harris

The Harlequin was in full breeding plumage with an unmistakable black and white pattern on the head and neck, rusty flank and white line above the wing. The bird was surprisingly tame, paying no attention to the nearby activity on shore, and fed continuously during 45 minutes of observation. His dives were well timed: he dove about 30 feet upstream from the edge of the weir, surfacing 3 feet from the lip of the weir, seeming certain to go over, only to swim back upstream and dive again.

The Harlequin remained for 5 days during which time he was observed by several members of the Saskatoon Natural History Society. The duck was last observed on the evening of June 26 at which time he was resting on the river well out from shore.

This sighting is the first for the Saskatoon area and the sixth for Saskatchewan. The previous records 